\title{
Evaluation of nuts morphology and composition of fatty acids in cer- tain Iranian Pistacia vera L. (Anacardiaceae) cultivars
}

\author{
Mojdeh MAHDAVI ${ }^{1}$, Fariba SHARIFNIA ${ }^{1,2}$, Fahimeh SALIMPOUR ${ }^{1}$, Akbar ESMAEILI ${ }^{3}$ \& Mohadde- \\ seh LARYPOOR ${ }^{4}$
}

Received August 08, 2020; accepted May 07, 2021.

Delo je prispelo 8. avgusta 2020, sprejeto 7. maja 2021

\begin{abstract}
Evaluation of nuts morphology and composition of fatty acids in certain Iranian Pistacia vera L. (Anacardiaceae) cultivars

Abstract: Fruits of various Pistachio (Pistacia vera L.) cultivars are widely used in food industries for its inimitable color, taste and nutrient value. We elevated fruit morphology and kernel fatty acids composition of eleven Iranian cultivars of pistachio. Oils of kernels were extracted using cold press method, and composition of the oil fatty acids in the methyl ester form was detected using gas chromatography (GC). For morphological study, nine qualitative and quantitative traits were evaluated. The quantitative ones widely differed among the studied cultivars, and ANOVA test revealed the significant variations $(p=0.00)$ for all of them. Moreover, the qualitative traits varied among the cultivars. We characterized 11 fatty acid components representing about 99.56 to $100 \%$ of the total oil composition. The principal fatty acids for all the cultivars were: oleic, linoleic and palmitic acids, while their amounts differed among the cultivars. In this regard, unsaturated fatty acids comprised the major oil part, 87.46 to $88.89 \%$. Oleic acid (53.11$70.99 \%)$ and palmitic acid (9.09 to $10.55 \%$ ) were detected as the unsaturated and saturated fatty acids in all the evaluated cultivars. The quality index of oils were determined according to oleic/ linoleic acids ratio, which highly varied among the cultivars. According to UPGMA tree and PCO plot, we divided the investigated cultivars into four chemotypes, and each of them was characterized by the certain oil composition.
\end{abstract}

Key words: saturated fatty acid; unsaturated fatty acid; pistachio; gas chromatography; Iran
Ovrednotenje morfologije oreščkov in sestave maščobnih kislin v nekaterih iranskih sortah pistacije, Pistacia vera L. (Anacardiaceae)

Izvleček: Plodovi/semena različnih sort pistacije (Pistacia vera L.) se naširoko uporabljajo $\mathrm{v}$ prehrambeni industriji zaradi njihove neposnemljive barve, okusa in hranilne vrednosti. V raziskavi smo dali poudarek na morfologijo plodov in sestavo maščobnih kislin $\mathrm{v}$ jedrcih enajstih iranskih sort pistacije. Olja iz jedrc so bila hladno stisnjena, sestava maščobnih kislin je bila $\mathrm{v}$ obliki metil estrov določena s plinsko kromatografijo (GC). $\mathrm{V}$ morfološki raziskavi je bilo ovrednoteno devet količinskih in kakovostnih lastnosti. Količinske lastnosti so se med sortami zelo razlikovale in ANOVA test je odkril med vsemi značilne razlike $(p=0.00)$. Tudi kakovostne lastnosti so se med sortami razlikovale. Določili smo 11 maščobnih kislin, ki so predstavljale okrog 99,56 do $100 \%$ celokupne sestave olja. Najpomembnejše maščobne kisline v vseh sortah so bile oleinska, linolenska in palmitinska kislina, pri čemer se je njihova količina $\mathrm{v}$ posameznih sortah razlikovala. $\mathrm{V}$ tem pogledu so nenasičene maščobne kisline sestavljale večji del olja, od 87,46 do $88,89 \%$. Oleinska kislina $(53,11-70,99 \%)$ in palmitinska kislina (9,09-10,55 \%) sta bili ugotovljeni kot nenasičena in nasičena maščobna kislina $\mathrm{v}$ vseh ovrednotenih sortah. Kakovostni indeks olja, določen kot razmerje med oleinsko in linolensko kislino, se je med sortami zelo razlikoval. Glede na razvrstitve v UPGMA drevesu in PCO polju smo preučene sorte razdelili $\mathrm{v}$ štiri kemotipe, od katerih je imel vsak posebno sestavo olja.

Ključne besede: nasičena maščobna kislina; nenasičena maščobna kislina; pistacija; plinska kromatografija; Iran

1 Department of Biology, North Tehran Branch, Islamic Azad University, Tehran, Iran

2 Corresponding author, email: fa.sharifnia@gmail.com, f_sharifnia@iau_tnb.ac.ir

3 Department of Chemical Engineering, North Tehran Branch, Islamic Azad University, Tehran, Iran

4 Department of Microbiology, North Tehran Branch, Islamic Azad University, Tehran, Iran 


\section{INTRODUCTION}

The genus Pistacia L. belongs to Anacardiaceae, order Sapindales according to APG III (2009). Phylogenetic analyses according to phenotypical characteristics revealed that the genus definite as a monophyletic group and comprises of two sections: Pistacia and Lentiscus (AL-Saghir, 2009).

Taxa of the genus are deciduous or evergreen and dioecious trees, with stems up to $9 \mathrm{~m}$ high. The leaves are pinnately-compound containing round-ovate to elliptical leaflets. Female as well as male flowers are apetalous, wind-pollinated, subtended by small bracts and bracteoles, arranged in panicles or racemes inflorescences. In male flowers, 4-5 anthers are arranged on a disc. Female flowers have a short, 3-fided style and produce a drupe fruit (AL-Saghir, 2006; Khatamsaz, 1989).

According to several studies (Parfitt and Badenes, 1997; Kafkas and Perl-Treves, 2001; Kafkas et al., 2002), the genus had been originated in Central Asia more than 75 million years ago, and has two genetic diversity centers (1) Mediterranean region of Europe, Northern Africa, as well as the Middle East, and (2) West (Eastern slopes of Zagros mountains in Iran) and Central Asia (Crimea to the Caspian Sea).

Pistacia vera L. (cultivated pistachio) belongs to section Pistacia and based on RAPD molecular data, $P$. khinjuk Stocks and P. vera are closely related taxa (AlSaghir, 2009).

Zohary (1952) believed that pistachio is the ancestral species and other Pistachia taxa are probably its derivatives. It is the only Pistachia commercially cultivated species, and the others are mostly employed as rootstocks (Bozorgi et al., 2013)

Pistachio is ecologically adapted to a wide range of soil conditions and is probably more tolerant to saline and alkaline soil than most other crops. Besides, these trees grow in hot and dry desert-like habitats (Tous and Ferguson, 1996).

Based on the FAO (2010) reports, Iran, USA, Turkey and Syria are considered as the major producers of pistachio in the world.

Pistachio has several bioactive compounds, which the body of human can assimilate and use them (Noguera-Artiaga et al., 2019). For example, its fruit is considered as the food material with the largest antioxidant capacity and also a rich source of phenolic metabolites (Noguera-Artiaga et al., 2019; Dreher, 2012). The nuts of this tree contain several flavonoids such as cyanindin-3-O-glucoside, quercetin, kaempferol and epicatechin.

Moreover, Mandalari et al. (2013) suggested that polyphenol compounds of this nut is biologically acces- sible during simulated human digestion, consequently nearly $91 \%$ of its total amount release in the gastric organ.

Several studies (Kasliwal et al., 2015; Kocyigit et al., 2006; Dreher, 2012) revealed that pistachio nuts have a larger amount of monounsaturated fatty acids and a lower ratio of polyunsaturated to saturated fatty acids, in comparison with other nuts. It reveals that pistachio has cholesterol-reducing potential, and its low glycemic index reduces the diabetes risk.

The physical properties (morphology) of fruit such as length, width, diameter and color are considered as the important features which influence consumer preference in pistachio fruit (Zarei et al., 2014).

Although, there have been some studies on the fruit morphological characteristics and composition of fatty acids of pistachio cultivars from Iran (Roozban et al., 2006; Mazinani et al., 2012; Abdoshahi et al., 2011; Esteki et al., 2019; Yahyavia et al., 2020) and other countries (Dogan ,et al. 2010; Satil et al. 2003; Arena et al. 2007), these studies did not include all pistachio cultivars. So in the current evaluation, we studied the morphological characteristics and composition of the fatty acids in eleven Iranian pistachio cultivars. The aims of the study were: (1) to determine morphological variability in qualitative and quantitative fruits characteristics, (2) to study fatty acids composition of kernels, and (3) to detect quality index of kernels oil. As far as we could search, two cultivars have been studied for the first time in the world, including: 'Fakhri' and 'MengharKalaghi'.

\section{MATERIAL AND METHODS}

\subsection{PLANT SAMPLES}

Plant materials of the current study were the fruits of eleven pistachio cultivars which were harvested from Semnan province (Table 1).

We harvested pistachio fruits and after morphological examinations, removed their shells and dried in an oven at $55^{\circ} \mathrm{C}$ for $72 \mathrm{~h}$.

\subsection{MORPHOLOGICAL STUDIES}

In order to compare the fruits of cultivars morphologically, nine qualitative and quantitative characteristics were studied: fruit length, width, length/width ratio, and diameter, epicarp color, kernel coat color, kernel color and endocarp apical shape. The quantitative traits were measured based on the method described 
Table 1: Codes, names and localities of cultivars.

\begin{tabular}{lll}
\hline Code & Name of cultivars & Localities \\
\hline A & Kalleh Ghochi-white & Semnan province,Damghan,Saleh Abad village. \\
B & Shahpasand white & Semnan province, Damghan, Saleh Abad village. \\
C & Akbari red & Semnan province, Damghan, Saleh Abad village. \\
D & Khanjari & Semnan province, Damghan, Saleh Abad village. \\
E & Kalleh-Ghochi red & Semnan province, Damghan, Saleh Abad village. \\
F & Shahpasand red & Semnan province, Damghan, Saleh Abad village. \\
G & Fakhri & Semnan province, Damghan, Saleh Abad village. \\
H & Akbari white & Semnan province, Damghan, Saleh Abad village. \\
I & Abasali & Semnan province, Damghan, Saleh Abad village. \\
K & Ahmad Aghaei & Semnan province, Damghan, Saleh Abad village. \\
L & Menghar Kalaghi & Semnan province, Damghan, Saleh Abad village. \\
\hline
\end{tabular}

by Gavit (1990). The seed dimension measurements including width and length were performed by a standard ruler. The fruit length was measured parallel to hilum, while the fruit width was measured at the fruit broadest part. We investigated the qualitative characteristics according to descriptive terminology of Stearn (1985).

\subsection{OILS EXTRACTION AND PREPARATION OF THEIR METHYL ESTERS}

The oil extraction was performed by pressing of $100 \mathrm{~g}$ pistachio kernels of each cultivar using Oilmaster machine by cold press method. The process was done two times and the very tinny and fine kernels parts in the extracted oil were separated by filtration. Then, the filtered oil was centrifuged (Saber-Tehrani et al., 2013). We prepared fatty acids methyl esters dissolving of 0.4 $\mathrm{g}$ pistachio fruit oil in $4 \mathrm{ml}$ of isooctane and methylated in $0.2 \mathrm{ml}$ of $2 \mathrm{M}$ methanolic $\mathrm{KOH}$. The prepared oils were kept at $-18^{\circ} \mathrm{C}$ for further analyses.

\subsection{FATTY ACIDS IDENTIFICATION}

Analysis of fatty acid methyl ester was done on a Shimadzu (Nexis 2030) gas-chromatography (GC) equipped with Dikmacap 2330 FID (Flame Ionization Detector) detector, fused silica capillary column $(60 \mathrm{~m}$ $\times 0.25 \mathrm{~mm}$ i. d., $0.25 \mu \mathrm{m}$ film thickness). The carrier gas was helium at a flow rate of $2 \mathrm{ml} \mathrm{min}^{-1}$ in a split ratio of $1: 60$. Injector and detector temperatures were kept at 250 and $260^{\circ} \mathrm{C}$, respectively. The column temperature was initially kept at $60^{\circ} \mathrm{C}$ for $2 \mathrm{~min}$ and then amplified to $200{ }^{\circ} \mathrm{C}$ at a rate of $10^{\circ} \mathrm{Cm} \mathrm{min}-1$ and hold at the final temperature $240{ }^{\circ} \mathrm{C}$ for $7 \mathrm{~min}$. We detected the fatty acid methyl esters by retention time comparison and equivalent chain length with respect to standard FAMEs. For this, $1.0 \mu \mathrm{l}$ of FAMEs dissolved in petroleum ether was injected directly into gas chromatograph for analysis using a split ratio of $30: 1$. Besides, we computed the relative percentages of detected fatty acids from the GC peak area. We detected the quality index of kernels fatty acids using the ratio of oleic to linoleic acids $(\mathrm{O} / \mathrm{L})$. The index is commonly used as a measure to predict the shelf life and stability of the oil (Esteki et al., 2019).

\subsection{STATISTICAL ANALYSES}

We expressed the morphological data as mean \pm standard deviation. In addition, one-way analysis of variance (ANOVA) test was carried out to evaluate the morphological quantitative variables significant variations $(p=0.00)$ among the studied cultivars.

For clustering analyses of the evaluated cultivars, we standardized the quantitative data (mean $=0$, variance $=1$ ) and used for Principal Coordinate Ordination (PCO), Unweighted Paired Group using Average method (UPGMA) and Principal Correspondence Analysis (PCA) by MVSP according to Talebi et al. (2020).

\section{RESULTS}

\subsection{MORPHOLOGICAL STUDY}

The investigated morphological traits have been summarized in Table 2. Fruit qualitative morphological traits varied among the evaluated cultivars (Fig. 1). The 
epicarp color varied as yellowish pink (Kalleh-Ghochi white, Khanjari, Akbari white and Ahmad-Aghaei cultivars), purple (Shahpasand white, Akbari red, KallehGhochi red and Fakhri cultivars), pink (Shahpasand red and Abasali cultivars) and yellowish orange (MengharKalaghi cultivar).

In addition, we registered kernel coat color as purple (Kalleh-Ghochi white and Ahmad- Aghaei cultivars), purple brown (Shahpasand white and Khanjari cultivars), pink (Kalleh-Ghochi red, Fakhri, Akbari white, Abasali and Menghar-Kalaghi cultivars) and purple pink (Akbari red and Shahpasand red cultivars).

The color of kernels observed as yellowish (KallehGhochi white, Khanjari, Fakhri, Abasali and AhmadAghaei cultivars), pea green (Shahpasand white, Akbari red, Kalleh-Ghochi red and Shahpasand red cultivars) and green (Akbari white and Menghar-Kalaghi cultivars).

Besides, quantitative variables changed among the investigated cultivars. In this regard, the largest (3 $\mathrm{cm})$ and smallest $(1.8 \mathrm{~cm})$ fruit lengths were observed in Kalleh-Ghochi red, Ahmad-Aghaei and MengharKalaghi cultivars, respectively.

The broadest $(1.7 \mathrm{~cm})$ fruit belonged to Menghar-Kalaghi cultivar, while the narrowest $(1.1 \mathrm{~cm})$ was recorded in Shahpasand red cultivar. Moreover, the longest $(1.8 \mathrm{~cm})$ and shortest $(1 \mathrm{~cm})$ fruit diameters belonged to Shahpasand white and Ahmad-Aghaei cultivars, respectively. Moreover, the ANOVA test revealed significant difference $(p=0.00)$ for all the quantitative morphological characteristics (Table 2).

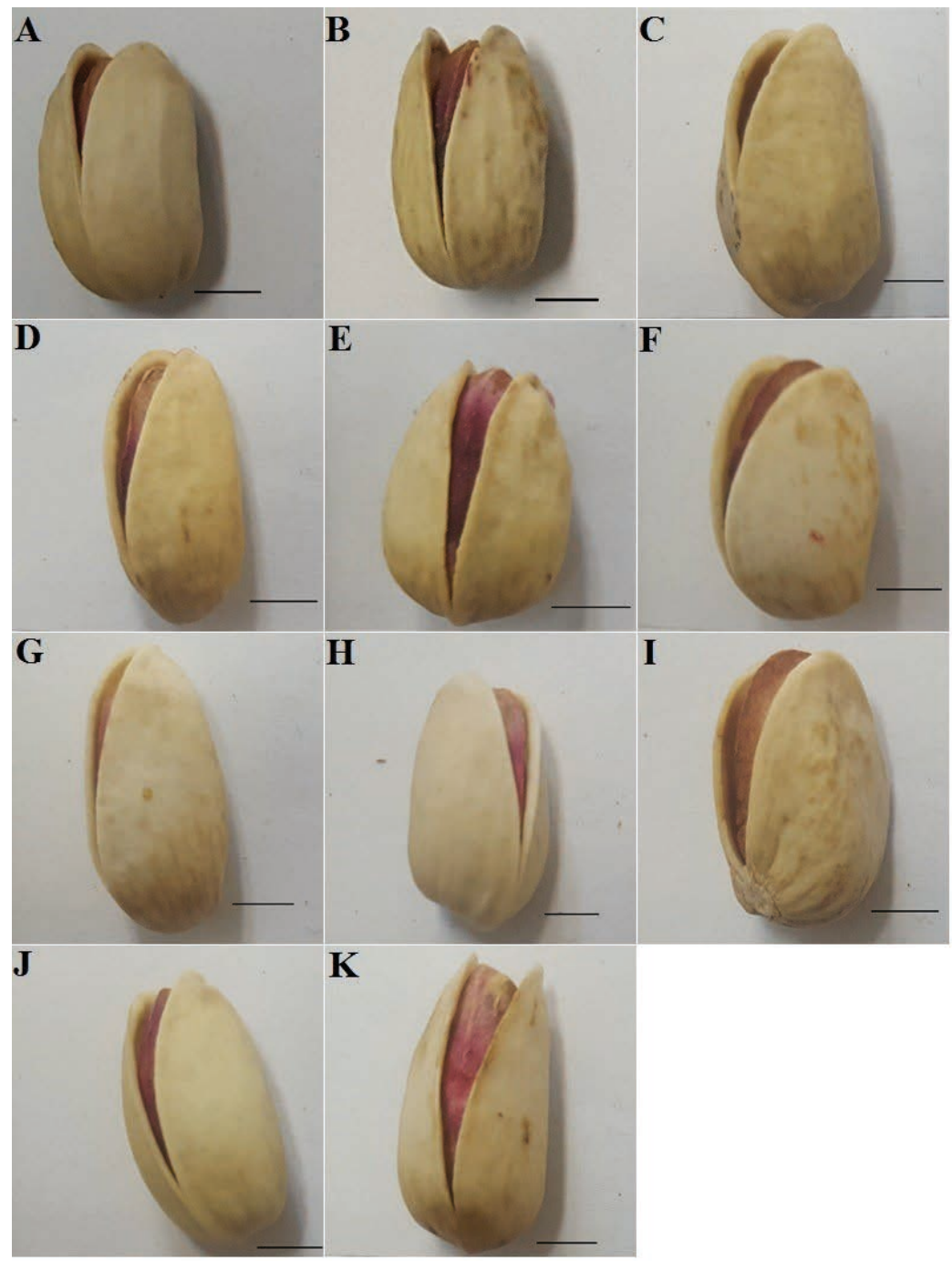

Fig. 1: Fruit shape of the investigated pistachio cultivars (the letters indicate cultivars name according to table 1, scale bar 5 $\mathrm{mm}$ ) 


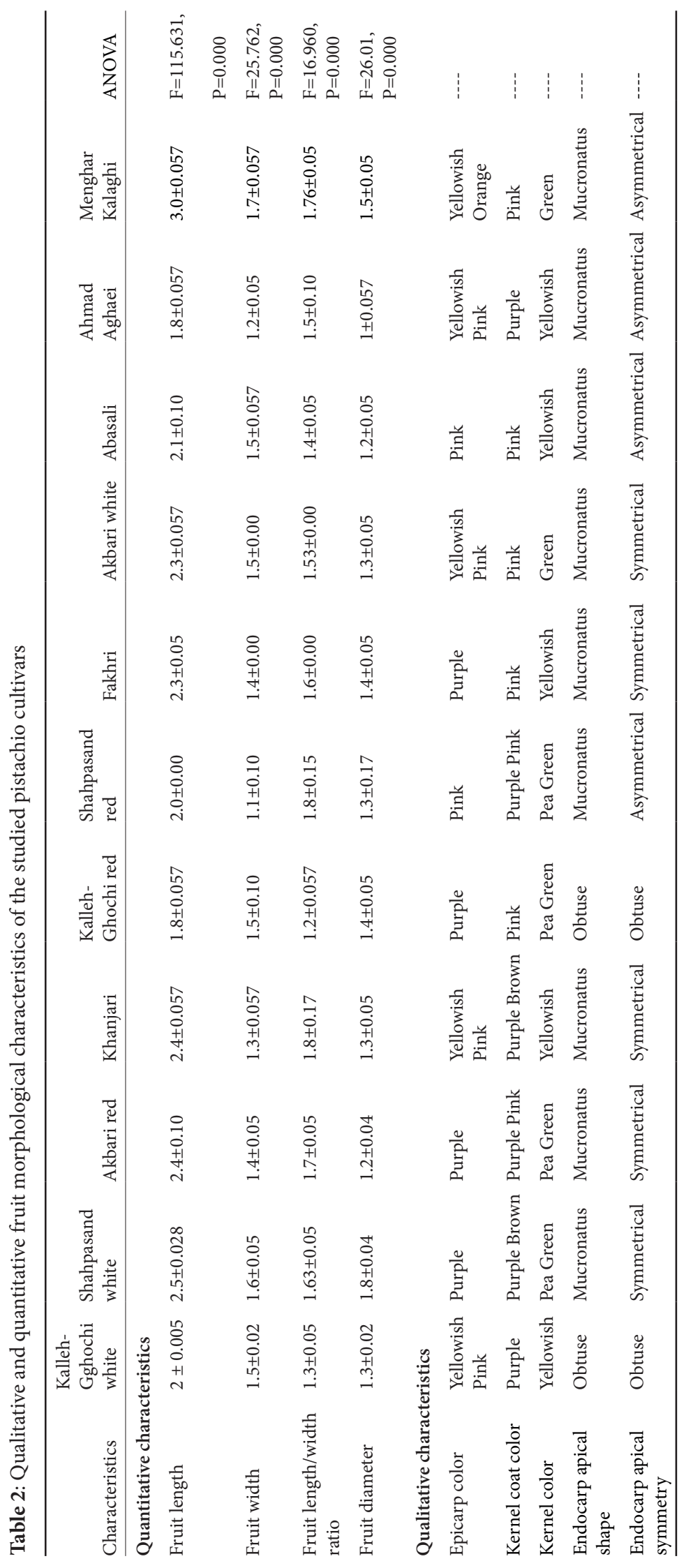




\subsection{FATTY ACIDS COMPOSITION}

The oil composition, unsaturated and saturated fatty acids percentages, of the evaluated pistachio cultivars kernels are listed in Table 3. The amounts of mono and polyunsaturated and saturated fatty acids differed from 87.46 to $89.68 \%$, and 10.48 to $12.01 \%$, respectively.

The oleic, linoleic and palmitic acids were detected the principal fatty acids for all the cultivars. However, the amounts of other fatty acids did not exceed more than $1.6 \%$.

Oleic (omega-9) and linoleic (omega-6) acids were the most abundant unsaturated fatty acids. The oleic acid, first main polyunsaturated fatty acid, ranged from 53.11 (Menghar-Kalaghi cultivar) to $70.99 \%$ (KallehGhochi white cultivar), with the general mean of 60.78 $\%$.

The second main fatty acid was linoleic, which its percentages ranged from 15.01 (Kalleh-Ghochi white cultivar) to $33.11 \%$ ( Menghar-Kalaghi cultivar), with the average amount of $25.75 \%$.
The palmitic acid was the first main saturated fatty acid which ranged from 9.09 \% (Kalleh-Ghochi red cultivar) to $10.55 \%$ (Shahpasand red cultivar), and the average amount for all the cultivars was $9.9 \%$.

We estimated the quality index of the studied cultivars oils based on oleic/linoleic acids ratio and reported that Kalleh-Ghochi white cultivar contained the largest amount (4.72) and Menghar-Kalaghi cultivar had the lowest value (1.60). According to UPGMA tree (Fig 2), the studied cultivars were divided into 4 chemotypes; I) Kalleh-Ghochi white cultivar, II) Shahpasand white, Akbari red and Shahpasand red cultivars, III) Khanjari, Kalleh-Ghochi red, Abasali and Akbari white cultivars, and IV) Fakhri, Ahmad-Aghaei and Menghar-Kalaghi cultivars. In addition, the PCA and PCO plots produced similar results (Fig. 3, 4). According to both plots, axis 1 act as a cut factor and divided the studied cultivars into two clades. Then, each clade was subdivided into two groups: Kalleh-Ghochi white cultivar was grouped separately in both plots. However, other cultivars were clustered in three groups.

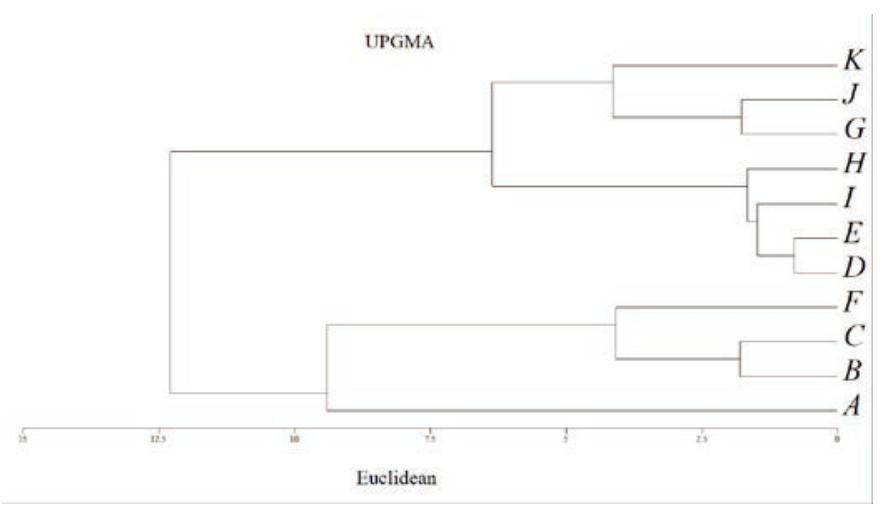

Fig. 2: UPGMA tree of the investigated pistachio cultivars based on the fatty acids compositions (letters indicated the cultivars name according to Table 1)

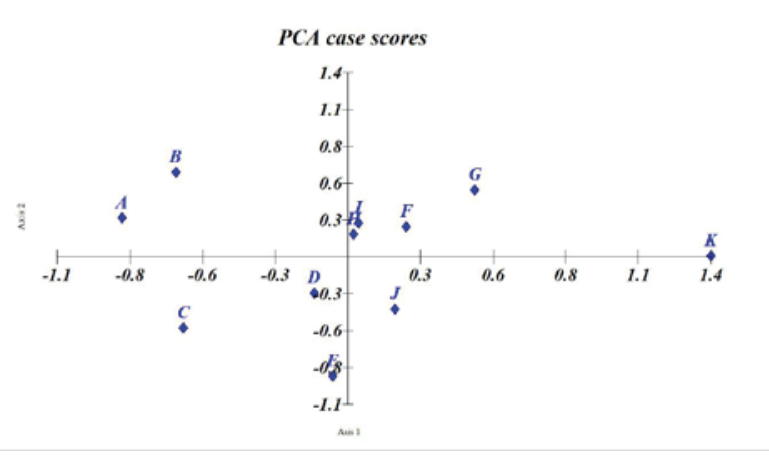

Fig.3: PCA plot of the studied cultivars of pistachio according to fatty acids compositions (letters indicated the cultivars name according to Table 1)

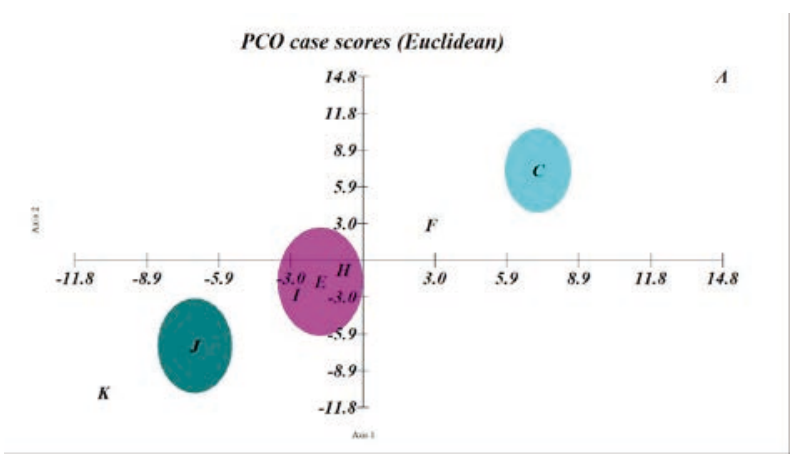

Fig. 4: PCO plot of the evaluated pistachio cultivates according to fatty acids composition (letters indicated the cultivars name according to Table 1) 


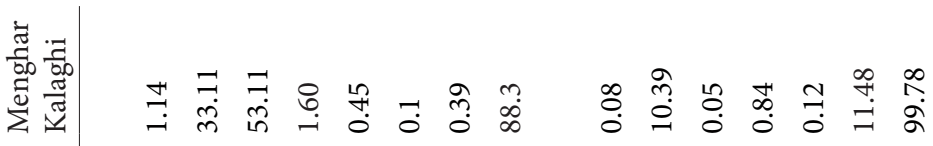

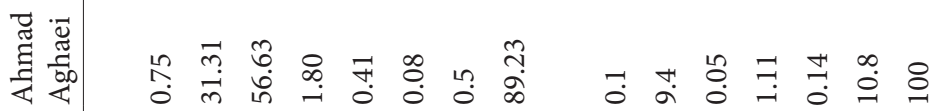

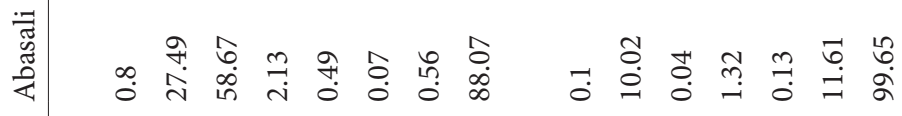

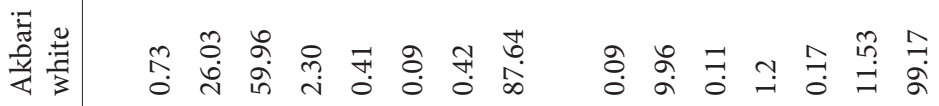

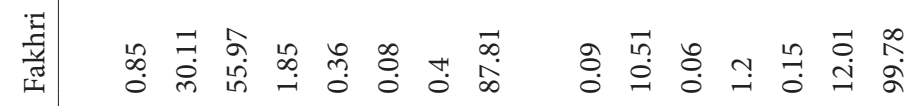

त्ञ్त

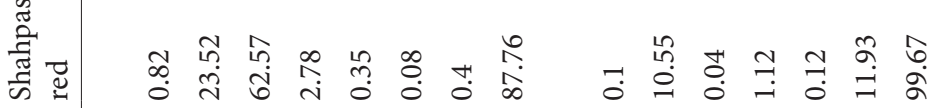

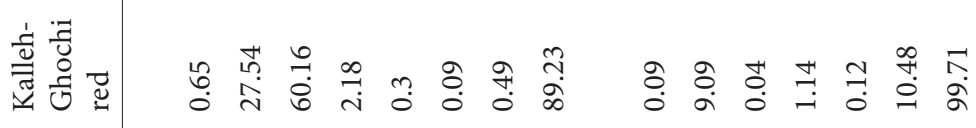

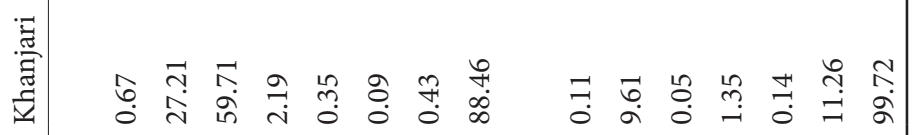

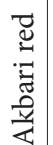

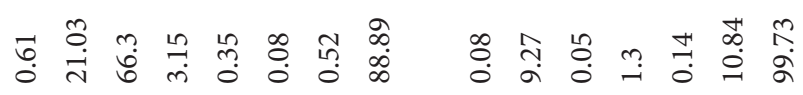

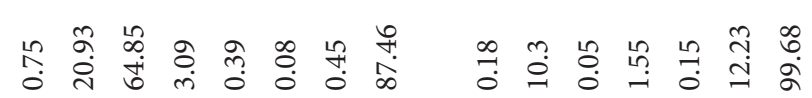

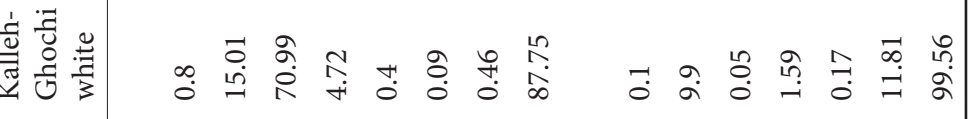

$\begin{array}{llllllllllll}0 & 0 & 0 & 0 & 0 & 0 & 0 & 0 & 0 & 0 & 0 & 0\end{array}$ 


\section{DISCUSSION}

We elevated the fruit morphological characteristics and kernels fatty acids compositions in eleven cultivars of pistachio from Iran, the first pistachio producer of the world. Because, these findings are extremely important for both pistachio producers and consumers.

We selected all the cultivars from the same region in Iran, to eliminate the effects of environmental factors. According to different investigations the morphological and phytochemical features of pistachio nuts depend on habitat characteristics (Zur et al., 2008; Arena et al., 2007).

Morphological characteristics of fruit and kernels highly varied among the populations. Knowledge of morphological properties are very essential in equipment designing for sorting, transportation and storing of pistachio fruits (Kashaninejada et al., 2006).

Among the studied pistachio samples, MengharKalaghi cultivar possess the largest dimensions (including length, width and diameter) fruits, while the smallest pistachio fruits belonged to Ahmad-Aghaei cultivar. The fruits size of other cultivars were between the fruits size of Menghar-Kalaghi and Ahmad-Aghaei cultivars.

Zarei et al. (2014) studied fruit morphological characteristics of certain (Akbari, Kalleh-Ghuchi, Ohadi and Sephid) cultivars of pistachio and reported Akbari and Kalle-Ghouchi cultivars produce bigger fruit rather than the others. However, in the current research Menghar-Kalaghi cultivar possess the bigger fruit rather than Akbari and Kalle-Ghouchi cultivars. It seems that the cultivar may be useful in genetic breeding program of pistachio.

In addition, the color of fruit epicarp, kernel coat and kernel differed among the cultivars. It seems that different types of anthocyanins and some flavonoids such as lutein derivatives exist on the fruit are responsible for pistachio fruit color (Dreher, 2012).

Unsaturated fatty acids represent $87-89 \%$ of total fatty acids composition in the investigated pistachio cultivars. Among these fatty acids, oleic and linoleic acid play a significant role with amount of $53-70 \%$ and 15.01-33.11\%, respectively. Givianrad et al. (2011) suggested that the kernel oil of pistachio has been definite as an oleiclinoleic oil and could be used in culinary and food industries. Because, the oleic acid is most abundant fatty acid, and it was followed by linoleic acid.

However, the percentages of oleic and linoleic acids differed among the studied cultivars nearly 1.33 and 2.2 -folds, respectively. This profoundly affects the quality of pistachio oil. According to Roozban et al. (2006), the quality of pistachio fruit is depended on composi- tion of its fatty acids composition, chiefly with oleic and linoleic acids amounts.

Oleic acid has several usages in food industries. For example, it acts as food preservative and foods that prepared with the acid remains longer, even out of the refrigerator. Moreover, the acid possess the fungistatic property against a wide spectrum of saprophytic yeasts and moulds. This mono-unsaturated fatty acid possess several usages in hygiene products such as lotions, creams, lipsticks, detergents and soaps as softening agent and emollient(Saber-Tehrani et al., 2013).

The highest and the lowest amounts of oleic/ linoleic acids ratio were reported from Kalleh-Ghochi white and Menghar-Kalaghi cultivars, respectively. This ratio is called the quality index, and usually applied as a measure to predict the stability and shelf life of the fruit oil. Recently, Esteki et al. (2019) have suggested that the oxidative rancidity of pistachio oils develops with an increase in polyunsaturated fatty acids level. So, the higher amount of unsaturation fatty acids leads to the lower oil quality. A higher ratio reveals longer shelf life and chemical stability.

The quality index value varied nearly 3-times among the cultivars and fruits of Kalleh-Ghochi white cultivar have the longest shelf life and chemical stability, while the reverse pattern was found for Fakhri, AhmadAghaei and especially Menghar-Kalaghi cultivars. Similar results were reported by Esteki et al. (2019), which suggested that the large variation exists in fatty acids composition among the evaluated cultivars and also in quality index according to the oleic/linoleic acid ratio. Because oleic acid is considered as a monounsaturated acid and its higher amounts leads to a higher oxidative stability and consequently a large shelf life.

The main fatty acids of the oil were the same among the investigated cultivars. The findings agreed with previous investigations of Iranian and Turkish cultivars. For example, in several researches (Esteki et al., 2019; Yahyavia et al., 2020; Roozban et al., 2006; Mazinani et al., 2012; Abdoshahi et al., 2011) various Iranian pistachio cultivars including Qazvini, Ahmad-Aghaei, Akbari, Chrok, Kalle-Ghouchi, Ohadi, Damgani, Momtaz and Fandoghi were evaluated and the same fatty acids (oleic, linoleic and palmitic acids) were reported as the major fruit oil fatty acids. In addition, similar results were obtained from fatty acids composition of Turkish pistachio cultivars (Dogan et al., 2010; Arena et al., 2007; Satil et al., 2003).

These findings revealed that the kind of main chemical composition of pistachio kernel oil was comparatively homogeneous and have limited diagnosis value for cultivar identification. However, the observed 
quantitative variations in fatty acid may be related to small genetic divergence of the cultivars.

Farzad-Amirebrahimi et al. (2017) analyzed genetic diversity of 28 Iranian cultivars of pistachio using ISSR molecular marker and reported that $8 \%$ of total genetic variations belonged to among populations and the rest (92\%) related to within population's one. In this regard, they suggested that the low among population's differences could be due to low genetic divergence in the primary parental populations.

All of our harvested cultivars were selected from Damghan in North-east of Iran, and it seems that all of them have the same parental taxon. According to previous investigations (Aalami et al., 1996; Mirzaei et al., 2005; Ahmadi-Afzadi et al., 2007) Pistacia vera 'Sarakhs' is distributed as self-grown forests in North-east of the country and has very small genetic divergence with pistachio cultivars. Therefore, it seems that the Iranian pistachio cultivars have been originated from the same taxon.

Results of clustering analyses revealed that the studied cultivars were classified into four chemotypes. Each chemotype was characterized by a special chemical profile. For example, chemotype I (containing KallehGhochi white cultivar) possess the highest amount of oleic acid and lowest percentage of linoleic acid. In chemotype III (including Khanjari, Kalleh-ghochi red, Abasali and Akbari white cultivars), the percentages of the oil principal fatty acids were nearly equal. However, these cultivar grouping were not in agreement with results of previous Inter Simple Sequence Repeat (Noroozi et al., 2009) and Amplified Fragment Length Polymorphism (Ahmadi-Afzadi et al., 2007) molecular studies on the certain studied cultivars.

\section{CONCLUSION}

We elevated fruit morphology and kernel fatty acids composition of eleven Iranian cultivars of pistachio. Quantitative morphological characteristics varied among the cultivars and ANOVA test revealed significant difference for all of quantitative ones. The largest and the smallest fruit sizes belonged to Menghar-Kalaghi and Ahmad-Aghaei cultivars, respectively. Unsaturated fatty acids constituent the great part of fatty acid composition. Although the major fatty acids (oleic, linoleic and palmitic acids) of oil were the same among the cultivars, their value differed among them. The quality index of oil (oleic/ linoleic acids ratio) varied among the cultivars and its highest and lowest amounts were reported from Kalleh-Ghochi white and Menghar-Kalaghi, respectively. The index usually applied as a measure to predict the stability and shelf life of the fruit oils.

\section{REFERENCES}

Aalami, A., Nayeb, M. (1996). Using isozyme for genetic diversity analysis of Iranian pistachio. M.Sc. Thesis, Faculty of Agriculture, Tarbiat Modares University, Iran.

Abdoshahi, A., Mortazavi, S. A., Shabani, A. A., Elhamirad, A. H., Taheri, M. (2011). Evaluation of protein, fat and fatty acids content of the pistachio (Pistacia vera L.) cultivars of Damghan, Iran. International Journal of Nuts and Related Sciences, 2(4), 15-24.

Ahmadi-Afzadi, M., Sayed Tabatabaei, B. E., Mohammadi, S. A., Tajabadipur, A. (2007). Comparison of genetic diversity in species and cultivars of pistachio (Pistacia sp. L.) based on amplified fragment length polymorphism (AFLP) markers. Iranian Journal of Biotechnology, 5(3), 147-152.

AL-Saghir, M. G. (2009). Evolutionary history of the genus Pistacia (Anacardiaceae), International Journal of Botany, 5(3), 255-257. https://doi.org/10.3923/ijb.2009.255.257

APG III. (2009). An update of the angiosperm phylogeny group classification for the orders and families of flowering plants: APG III. Botanical Journal of the Linnean Society, 161, 105-121. https://doi.org/10.1111/j.10958339.2009.00996.x

Arena, E., Campisi, S., Fallico, B., Maccarone, E. (2007). Distribution of fatty acids and phytosterols as a criterion to discriminate geographic origin of pistachio seeds. Food Chemistry, 104, 403-408. https://doi.org/10.1016/j.foodchem.2006.09.029

Bozorgi, M., Memariani, Z., Mobli, M. Salehi Surmaghi, M. H., Shams-Ardekani, M. R., Rahimi, R. (2013). Five Pistacia species (P. vera, P. atlantica, P. terebinthus, P. khinjuk, and $P$. lentiscus): A review of their traditional uses, The Scientific World Journal, 33 pp. https://doi.org/10.1155/2013/219815

Dreher, M. L. (2012). Pistachio nuts: Composition and potential health benefits. Nutrition Reviews, 70(4), 234-240. https://doi.org/10.1111/j.1753-4887.2011.00467.x

Dogan, A., Çelik, F., Balta, F., Javidipour, I., Yavic A. (2010). Analysis of fatty acid profiles of pistachios (Pistacia vera L.) and native walnuts (Juglans regia L.) from Turkey. Asian Journal of Chemistry. 22(1), 517-521.

Esteki, M., Ahmadi, P., Heyden, Y. V., Simal-Gandara, J. (2019). Fatty acids-based quality index to differentiate worldwide commercial pistachio cultivars. Molecules, 24, 58. https:// doi.org/10.3390/molecules 24010058

FAO, Food and Agriculture Commodities, (2010). http:// www.fao.org/es/ess/top/commodity.html

Farzad-Amirebrahimi, F., Mahmoodnia-Meimand, M., Karimi, H. R., Malekzadeh, K. \& Tajabadipour A. (2017). Genetic diversity assessment of male and female pistachio genotypes based on ISSR markers. Journal of Plant Molecular Breeding, 5(1), 31-39. Doi: 10.22058/ JPMB.2017.63965.1132.

Gavit, N. C. (1990) A contribution to the study of systematic seed 
morphology of South Gujarat plants. Ph. D. Thesis, South Gujarat University, Surat.

Givianrad M. H., Saffarpour S. \&Beheshti, P. (2011). Fatty acid and triacylglycerol compositions of Capparis spinosa seed oil. Chemistry of Natural Compounds, 47(5), 798-799. https://doi.org/10.1007/s10600-011-0063-6

Kafkas, S., Perl-Treves, R. (2001). Morphological and Molecular Phylogeny of Pistacia species in Turkey, Theoretical and Applied Genetics, 102, 908-915. https://doi.org/10.1007/ s001220000526

Kashaninejada, M., Mortazavi, A., Safekordi, A., Tabil, L.G. (2006). Some physical properties of pistachio (Pistacia vera L.) nut and its kernel. Journal of Food Engineering, 72, 30-38. https://doi.org/10.1016/j.jfoodeng.2004.11.016

Kasliwal, R. R., Bansal, M., Mehrotra, R., Yeptho, K. P., Trehan, N. (2015). Effect of pistachio nut consumption on endothelial function and arterial stiffness. Nutrition, 31, 678-685. https://doi.org/10.1016/j.nut.2014.10.019

Khatamsaz, M. (1988). Flora of Iran, no.3, Anacardiaceae. Ministry of Agriculture and Natural Resources, research Institute of Forests and Rangelands, Tehran.

Kocyigit, A., Koylu, A. A., Keles, H. (2006). Effects of pistachio nuts consumption on plasma lipid profile and oxidative status in healthy volunteers. Nutrition, Metabolism Cardiovascular Diseases, 1693, 202-209. https://doi.org/10.1016/j. numecd.2005.08.004

Mandalari, G., Bisignano, C., Filocamo, A., Chessa, S., Sarò, M., Torre, G., Faulks, R. M. Dugo, P. (2013). Bioaccessibility of pistachio polyphenols, xanthophylls, and tocopherols during simulated human digestion. Nutrition, 29(1), 338344. https://doi.org/10.1016/j.nut.2012.08.004

Mazinani, S. Elhami Rad, A. H., Khaneghah, A. M. (2012). Determination and comparison of the amount of tocopherolic and phenolic compounds and fatty acids profile in edible nuts (Pistachio, Almond and Walnut) oil. Advances in Environmental Biology, 6, 1610-1619

Mirzaei, S., Bahar, M., Sharifnabi, B. (2005). A phylogenetic study of Iranian wild pistachio species and some cultivars using RAPD markers. Acta Horticulture, 726, 39-43. https://doi.org/10.17660/ActaHortic.2006.726.3

Noguera-Artiaga, L., García-Romo, J. S., Rosas-Burgos, E. C., Cinco-Moroyoqui, F. J., Vidal-Quintanar, R. L., CarbonellBarrachina, A. A. \& Burgos-Hernández, A. (2019). Antioxidant, antimutagenic and cytoprotective properties of Hydrosos pistachio nuts. Molecules, 24(23), 4362; https:// doi.org/10.3390/molecules24234362

Noroozi, S., Baghizadeh, A., Jalali Javaran, M. (2009). The genetic diversity of Iranian pistachio (Pistacia vera L.) cul- tivars revealed by ISSR markers. Biological Diversity and Conservation, 2, 50-56.

Parfitt, D. E. \& Badenes, M. L. (1997). Phylogeny of the gecnus Pistacia as determined from analysis of the chloroplast genome. Proceedings of the National Academy of Sciences of the United States of America, 94(15), 7987-7992. https://doi. org/10.1073/pnas.94.15.7987

Saber-Tehrani M., Givianrad M. H., Aberoomand-Azar P., Waqif-Husain S., and Jafari Mohammadi S. A. (2013). Chemical composition of Iran's Pistacia atlantica cold-pressed oil. Journal of Chemistry, https://doi.org/10.1155/2013/126106

Roozban, M. R., Mohamadi, N. \& Vahdati, K. (2006). Fat content and fatty acid composition of four Iranian pistachio (Pistacia vera L.) varieties grown in Iran. IV International Symposium on Pistachios and Almonds: Tehran, Iran; 726, 573-577. https://doi.org/10.17660/ActaHortic.2006.726.96

Stearn, W. T. (1985). Botanical Latin: history, grammar, syntax, terminology and vocabulary, 3rd ed. David \& Charles, Newton Abbot, UK

Satil, F., Azcan, N. \& Baser, K. H. C. (2003). Fatty acid composition of pistachio nuts in Turkey. Chemistry of Natural Compounds, 39(4), 322-324. https://doi.org/10.1023/ B:CONC.0000003408.63300.b5

Talebi, S. M., Amini, F., Askary, M., Farahani, S. \& Matsyura, A. (2020). Seed morphology and fatty acids composition among flax populations. Brazilian Journal of Botany, https://doi.org/10.100 7/s40415-020-00601-y

Tous, J. \& Ferguson L. (1996). Mediterranean Fruits. In: J. Janick, Ed., Progress in New Crops, ASHS Press, Ar- lington, , pp. 416-430.

Yahyavia, F., Alizadeh-Khaledabada, M., Azadmard-Damirchi, S. (2020). Oil quality of pistachios (Pistacia vera L.) grown in East Azarbaijan, Iran. NFS Journal, 18, 12-18. https:// doi.org/10.1016/j.nfs.2019.11.001

Zarei, M., Davarynejad, Gh., Abedi, B., Kafi, M., Biabani, A. (2014). Changes in physical properties, chemical composition and antioxidant activity of four pistachio cultivars at ten maturity stages. Advances in Environmental Biology, $8(10), 106-115$.

Zohary, M. (1952). A monographical study of the genus Pistacia. Palestine Journal of Botany (Jerusalem Series), 5(4), 187-228.

Zur, K., Heier, A., Blaas, K.W., Fauhl-Hassek, C. (2008). Authenticity control of pistachios based on $1 \mathrm{H}$ - and $13 \mathrm{C}$ NMR spectroscopy and multivariate statistics. European Food Research and Technology, 227, 969-977. https://doi. org/10.1007/s00217-007-0804-8. 